\title{
Control of the specificity of $T$ cell-mediated anti-idiotype immunity by natural regulatory $T$ cells
}

\author{
Max Warncke • Maike Buchner • Gudrun Thaller • \\ Anna Dodero · Alla Bulashevska · Dietmar Pfeifer • \\ Jens Timmer $\cdot$ Hendrik Veelken
}

Received: 12 July 2010/Accepted: 31 August 2010/Published online: 17 September 2010

(C) The Author(s) 2010. This article is published with open access at Springerlink.com

\begin{abstract}
The idiotypes of B cell lymphomas represent tumor-specific antigens. $\mathrm{T}$ cell responses induced by idiotype vaccination in vivo are directed predominantly against CDR peptides, whereas in vitro $\mathrm{T}$ cells also recognize framework-derived epitopes. To investigate the mechanisms regulating the specificity of idiotype-specific T cells, BALB/ $c$ or B10.D2 mice were immunized with mature dendritic cells loaded with $\mathrm{H}-2 \mathrm{~K}^{\mathrm{d}}$-restricted peptides from influenza hemagglutinin, or from shared (J region) or unique (CDR3) structures of the A20 lymphoma idiotype. Antigen-specific $\mathrm{T}$ cells were induced in vivo by the CDR3 and influenza epitopes, but not by the J peptide. Gene expression profiling of splenic regulatory $\mathrm{T}$ cells revealed vaccination-induced Treg activation and proliferation. Treg activity involved $\mathrm{J}$ epitope-dependent IL-10 secretion and functional suppression of peptide-specific effector T cells. Vaccination-induced in vivo proliferation of transgenic hemagglutinin-specific $\mathrm{T}$ cells was suppressed by co-immunization with the $\mathrm{J}$ peptide
\end{abstract}

Electronic supplementary material The online version of this article (doi:10.1007/s00262-010-0918-x) contains supplementary material, which is available to authorized users.

M. Warncke · M. Buchner · G. Thaller · A. Dodero .

A. Bulashevska - D. Pfeifer · H. Veelken

Department of Hematology/Oncology,

University Medical Center Freiburg, Freiburg, Germany

A. Bulashevska $\cdot$ J. Timmer

Department of Physics and Freiburg Center for Data Analysis and Modeling, University of Freiburg, Freiburg, Germany

H. Veelken $(\square)$

Department of Hematology, Leiden University Medical Center, P.O. Box 9600, Postzone C2-R-140, 2300 RC Leiden,

The Netherlands

e-mail: j.h.veelken@lumc.nl and was restored in CD25-depleted animals. In conclusion, Treg induced by a shared idiotype epitope can systemically suppress $\mathrm{T}$ cell responses against idiotype-derived and immunodominant foreign epitopes in vivo. The results imply that tumor vaccines should avoid epitopes expressed by normal cells in the draining lymph node to achieve optimal anti-tumor efficacy.

Keywords Idiotype - Lymphoma - Regulatory T cell · FoxP3

\section{Introduction}

Immunoglobulins contain unique primary sequences that are created by Ig gene rearrangement and may be diversified further by somatic hypermutation. The individual composition of immunogenic epitopes within the variable region of a given immunoglobulin is designated as "idiotype" (Id). Since the Id is an unique feature of the respective $\mathrm{B}$ cell clone, it represents an individual tumorspecific antigen of malignant B cell lymphomas [1]. Immunization of patients with indolent B cell lymphomas against their lymphoma-derived Id induces specific immune responses [2-6]. In patients immunized during clinical remission, induction of anti-Id antibodies is correlated with a favorable outcome [7, 8]. The role of Idspecific $\mathrm{T}$ cells for efficacious anti-lymphoma immunity is less clear.

In animal models, MHC class II-restricted T cells with specificity for hypermutated Id-derived epitopes exert immunosurveillance against the corresponding malignant $\mathrm{B}$ cell clone [9]. Augmentation of cellular anti-Id immunity by active immunization may also prevent tumor progression in experimental lymphoma models [9-11]. In contrast, 
A Peptide:

none
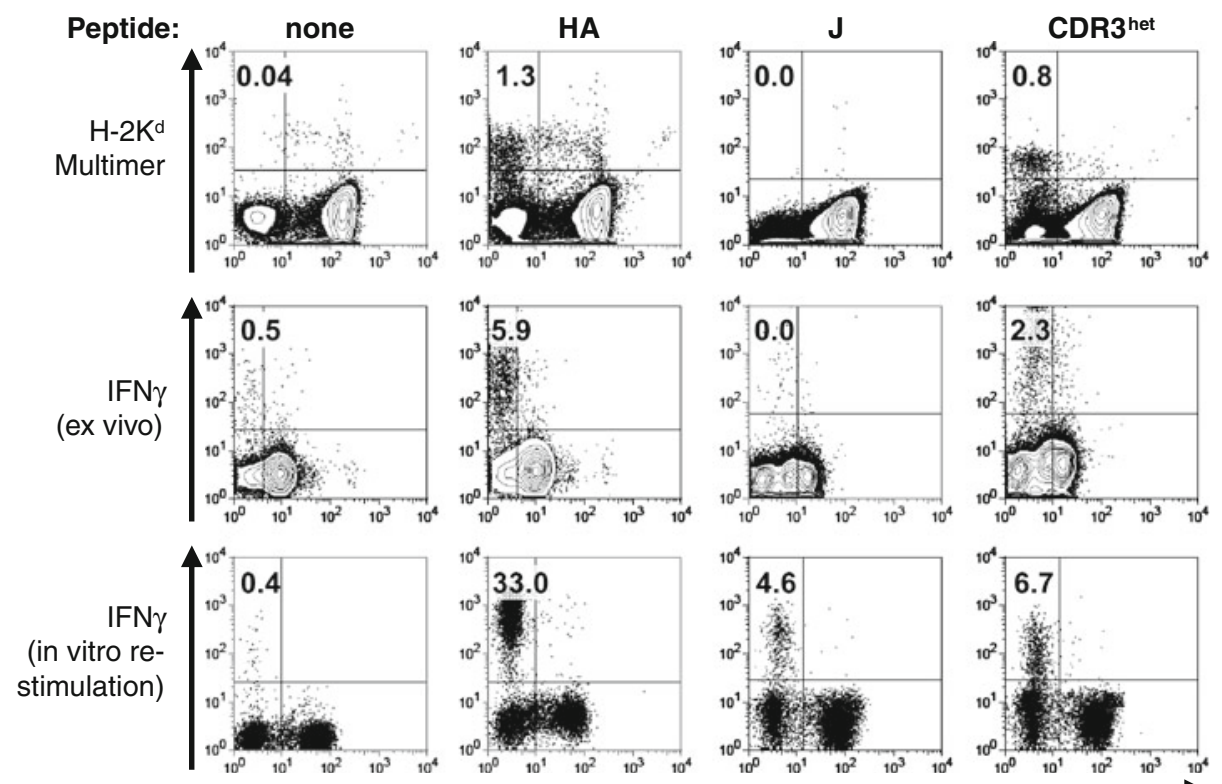

CD62L

B

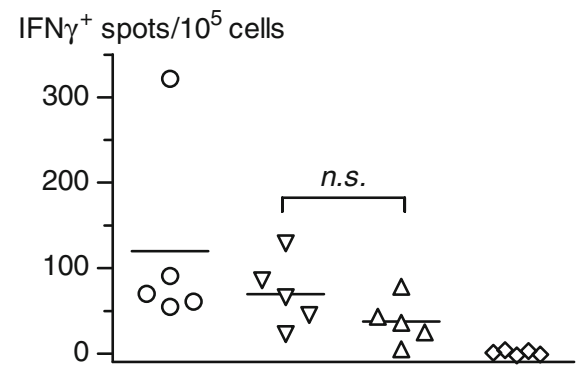

Restimulation: $\mathrm{HA} \mathrm{CDR}^{\text {het }} \mathrm{CDR}^{\text {nat }} \mathrm{J}$

Immunization: $\mathrm{HA} \quad \mathrm{CDR}^{\text {het }} \mathrm{J}$

C $M F I H-2 K^{d}$

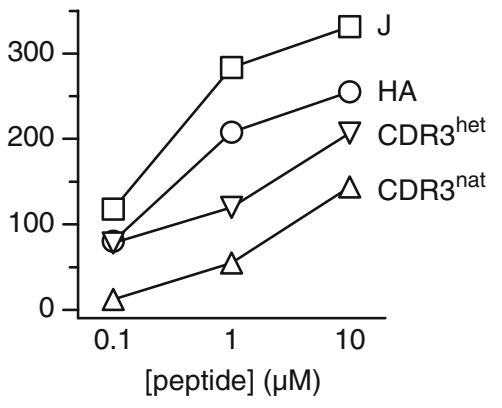

CDR3 ${ }^{\text {het. }}$

D non-immunized HA-immunized J-immunized immunized

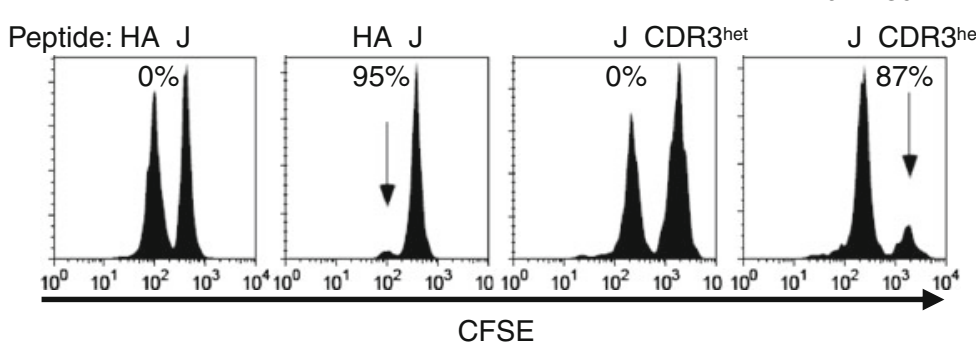

$\%$ Killing

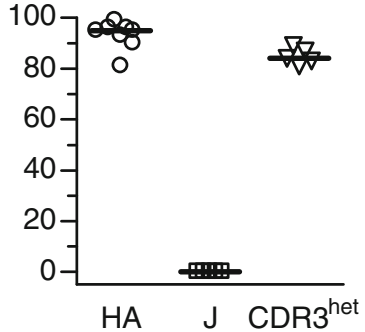

E

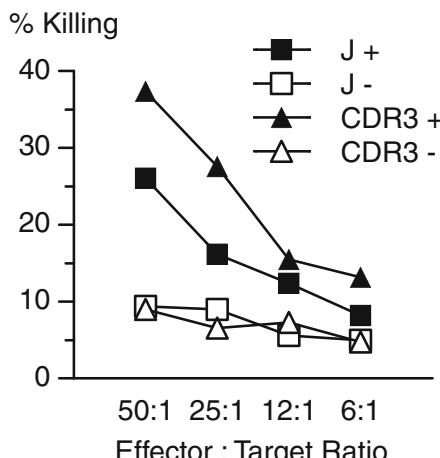

F IFN $\gamma^{+}$spots $/ 10^{5}$ cells

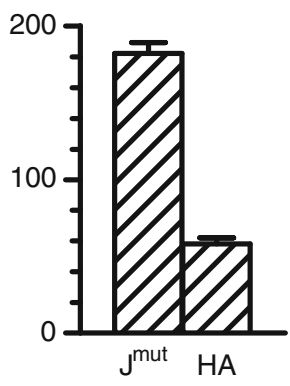

G \% Killing

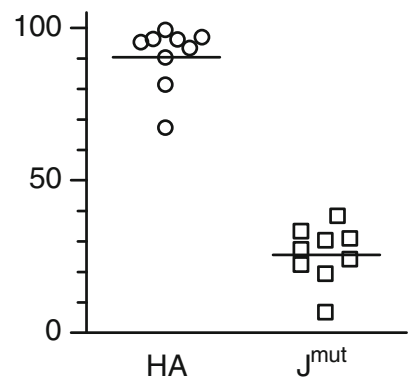


4 Fig. 1 Specific T cell responses after DC-based peptide immunization. a Representative measurement of peptide-specific $\mathrm{T}$ cells with gating on $\mathrm{CD}^{+}$cells and subtraction of controls with irrelevant multimer or peptide. Upper panel draining LN. Middle panel intracellular IFN- $\gamma$ production of splenocytes after overnight incubation with peptide. Lower panel intracellular IFN- $\gamma$ production of splenocytes after peptide restimulation for 8 days and subsequent incubation with peptide-pulsed $\mathrm{T} 2-\mathrm{K}^{\mathrm{d}}$ cells. b Recognition of the native CDR3 peptide $\left(C D R 3^{\text {nat }}\right)$ after immunization with heteroclitic CDR3 peptide $\left(C D R 3^{\text {het }}\right)$ as detected by ELISpot. Background spots with the respective irrelevant peptide (HA for CDR3 and J peptides; $\mathrm{CDR} 3^{\text {het }}$ for HA) were subtracted. c Measurement of peptide binding to $\mathrm{H}-2 \mathrm{~K}^{\mathrm{d}}$. After incubation of $\mathrm{T} 2-\mathrm{K}^{\mathrm{d}}$ cells with the indicated peptides for $24 \mathrm{~h}$, surface expression of $\mathrm{H}-2 \mathrm{~K}^{\mathrm{d}}$ was quantitated by flow cytometry. The MFI of unpulsed cells was subtracted. MFI mean fluorescence intensity. d In vivo cytotoxicity with peptide-loaded, CFSE-labeled splenocytes in the peripheral blood after immunization with the indicated peptides. Right panel summary of in vivo cytotoxicity in experimental groups. e In vitro cytotoxicity against peptide-loaded, CFSE-labeled T2 cells after restimulation of splenocytes for 8 days. $\mathrm{PI}^{+}$cells were measured within the $\mathrm{CFSE}^{+}$ population. $J+$ J-induced effectors, J-pulsed T2; J- J-induced effectors, CDR3-pulsed T2; CDR3+ CDR3-induced effectors, CDR3-pulsed T2; CDR3- CDR3-induced effectors, J-pulsed T2. f Ag-specific splenocytes after immunization with HA or modified J peptide $\left(J^{m u t}\right)$. g In vivo cytotoxicity against peptide-loaded, CFSElabeled splenocytes in the peripheral blood after peptide immunization. Symbols represent individual animals

the murine $\mathrm{T}$ cell repertoire is generally tolerant to germ line-encoded immunoglobulin sequences and may also be actively tolerized to individual Id epitopes [12].

We have previously described Id-specific, MHC class Irestricted cytotoxic $\mathrm{T}$ cells in lymphoma-bearing patients [13]. More recently, a reverse immunology bioinformatics study has indicated MHC class I-dependent immunosurveillance against individual CDRs of the Ids in human follicular lymphoma patients [14]. In accordance with the murine models, Id vaccination of patients induces in vivo preferentially $\mathrm{T}$ cells with specificity for CDR peptides or hypermutated epitopes $[3,15,16]$. In order to investigate the mechanisms governing the specificity of vaccinationinduced $\mathrm{T}$ cell immunity to Id in a wild-type immune repertoire, we performed comparative immunizations with a highly individual CDR3 epitope and a conserved FR epitope in a murine lymphoma model. A highly immunogenic influenza HA peptide [17] served as a reference standard for the analysis of immunization-induced $\mathrm{T}$ effector populations.

\section{Materials and methods}

Immunization

$1 \times 10^{6}$ DC matured and activated under serum-free conditions [18] were loaded with $\mathrm{H}-2 \mathrm{k}^{\mathrm{d}}$-restricted peptides
(Proimmune, Oxford, UK) and injected into the hind paw of $\mathrm{BALB} / \mathrm{c}$ or B10.D2 mice. For in vivo depletion of Treg, $500 \mu \mathrm{g}$ of anti-CD25 Ab PC61 (ATCC, Manassas, VA, USA) was injected i.p. 3 days prior to immunization. All in vivo experiments were performed at least three times.

In vivo assays

Ag-specific $\mathrm{T}$ cells were analyzed 1 week after immunization by flow cytometry with fluorochrome-labeled $\mathrm{Ab}$ (BD Biosciences or eBioscience, both in San Diego, CA, USA) and peptide-H- $2 \mathrm{~K}^{\mathrm{d}}$ multimers (Proimmune).

For in vivo detection of specific cytotoxicity, splenocytes were pulsed with $10 \mu \mathrm{g} / \mathrm{ml}$ antigenic or control peptide for $1 \mathrm{~h}$ at $37^{\circ} \mathrm{C}$ and labeled for $10 \mathrm{~min}$ separately with 0.5 or $5 \mu \mathrm{M}$ CFSE, respectively. $1 \times 10^{7}$ cells of each population were mixed and injected i.v. into recipient mice. After $24 \mathrm{~h}$, peripheral blood was analyzed by flow cytometry.

To measure vaccination-induced $\mathrm{T}$ cell proliferation, $1 \times 10^{6} \mathrm{CD}^{+}(\mathrm{CD} 8$ isolation kit, Miltenyi Biotech, Bergisch-Gladbach, Germany), CFSE-labeled $(5 \mu \mathrm{M})$ clone 4 cells were injected i.v. into congenic $\mathrm{CD} 45.2^{+}$mice 3 days after immunization. Clone $4 \mathrm{~T}$ cells (kindly provided by D.J. Morgan, University of Bristol) express a transgenic TCR with specificity for an immunodominant HA peptide [19]. 4 days after adoptive transfer, $\mathrm{CD} 8{ }^{+} \mathrm{CD} 45.1^{+} \mathrm{CD} 45.2^{-}$, $\mathrm{H}-2 \mathrm{~K}^{\mathrm{d}}$-multimer-positive splenocytes were analyzed for CFSE dilution.

Intracellular staining for IFN- $\gamma$

Effector cells were incubated for 5-16 h in the presence of $10 \mu \mathrm{M}$ peptide and $1 \mu \mathrm{l} / \mathrm{ml}$ GolgiStop (BD Biosciences). In restimulation experiments, $\mathrm{H}-2 \mathrm{~K}^{\mathrm{d}} \mathrm{T} 2$ cells (kind gift of S. Stevanovic, Tübingen, Germany) pulsed for $24 \mathrm{~h}$ with $10 \mu \mathrm{M}$ peptide were added as stimulators. After staining of cellular surface antigens, cells were fixed with $2 \%$ formaldehyde and stained in $0.5 \%$ saponin with XMG2 antiIFN- $\gamma$ Ab (BD Biosciences).

In vitro restimulation of $\mathrm{Ag}$-specific $\mathrm{T}$ cells

Splenocytes were cultured in FCS-supplemented RPMI medium with $10 \mu \mathrm{g} / \mathrm{ml}$ peptide. After 2 days, viable cells were recovered by Ficoll gradient centrifugation and cultured in medium supplemented with $50 \mathrm{U} / \mathrm{ml}$ rIL-2 (Peprotech, Rocky Hill, NJ, USA). Cells were analyzed after 7-9 days of restimulation. 

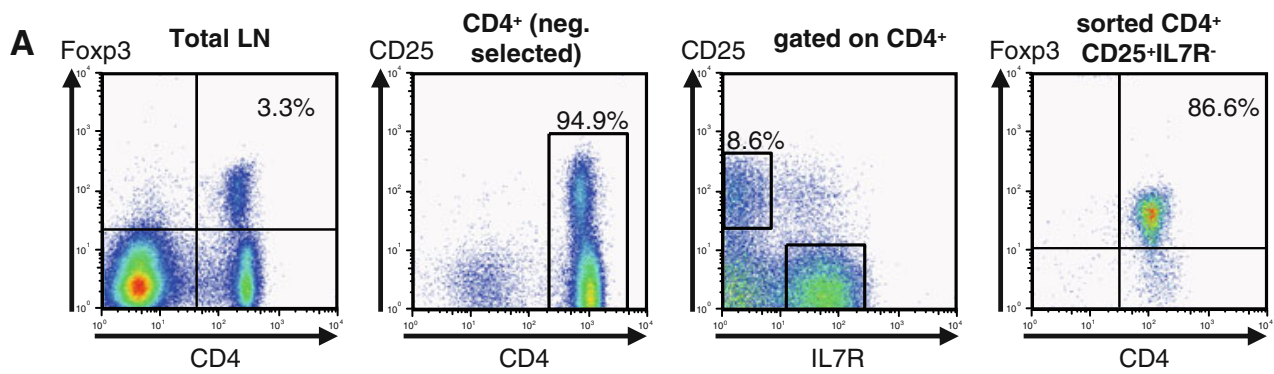

B
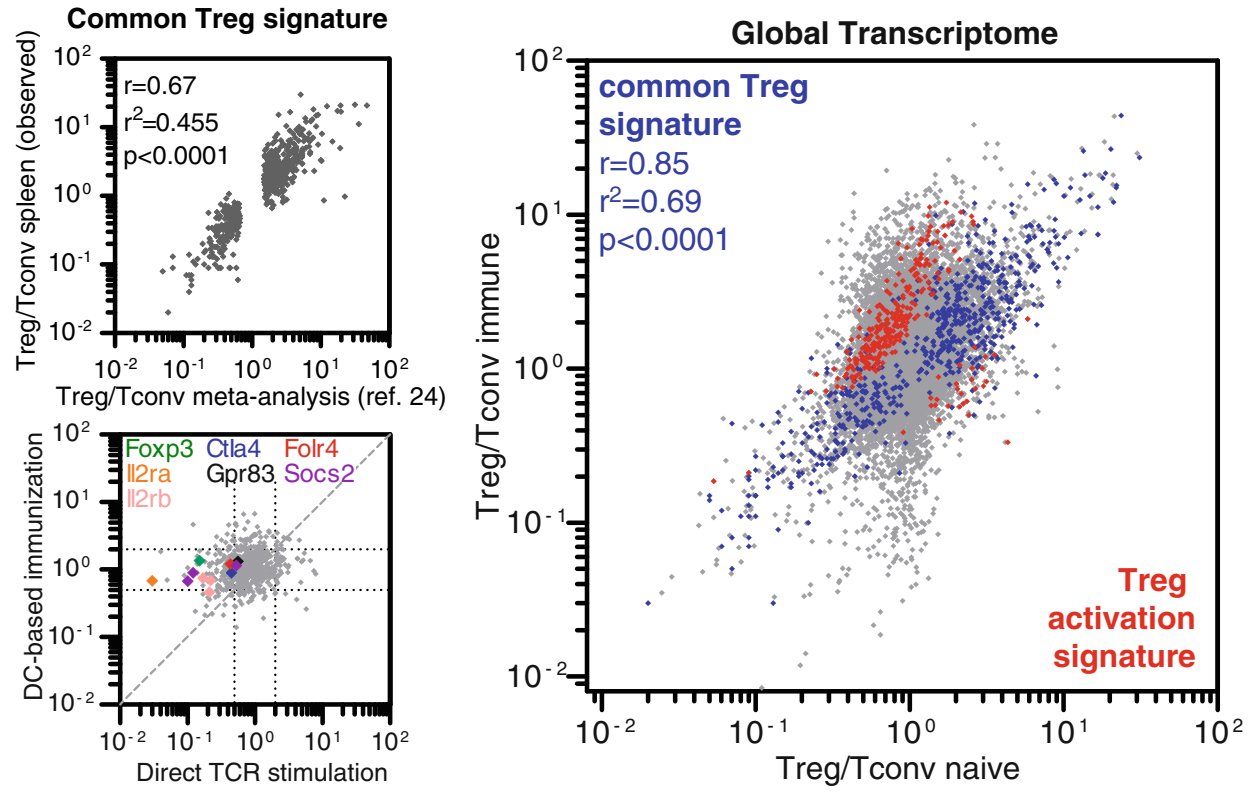

C
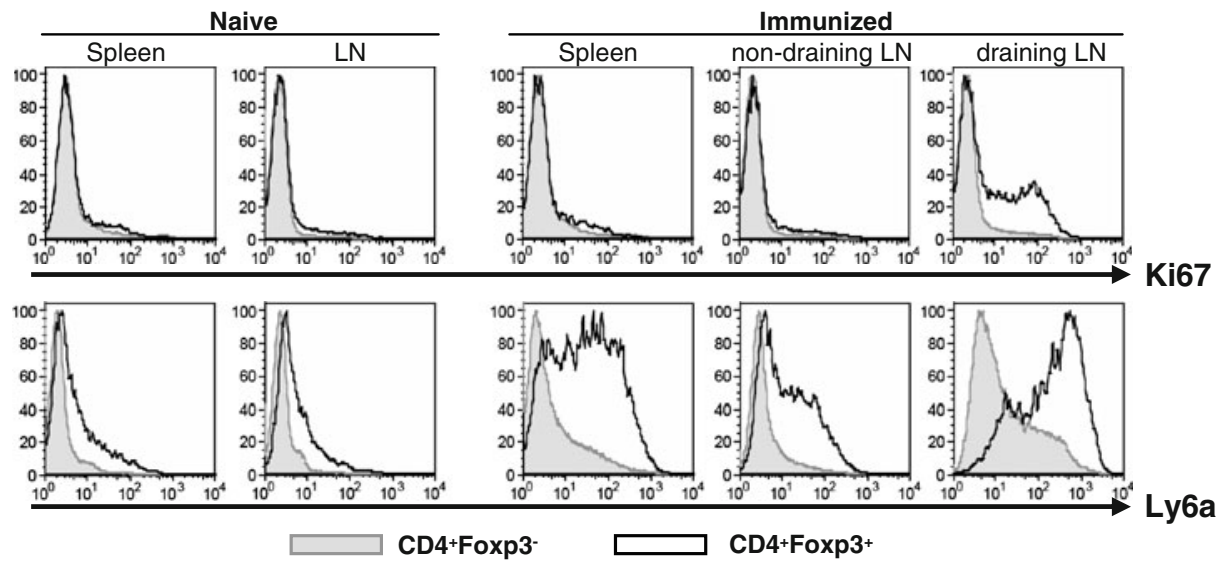

D

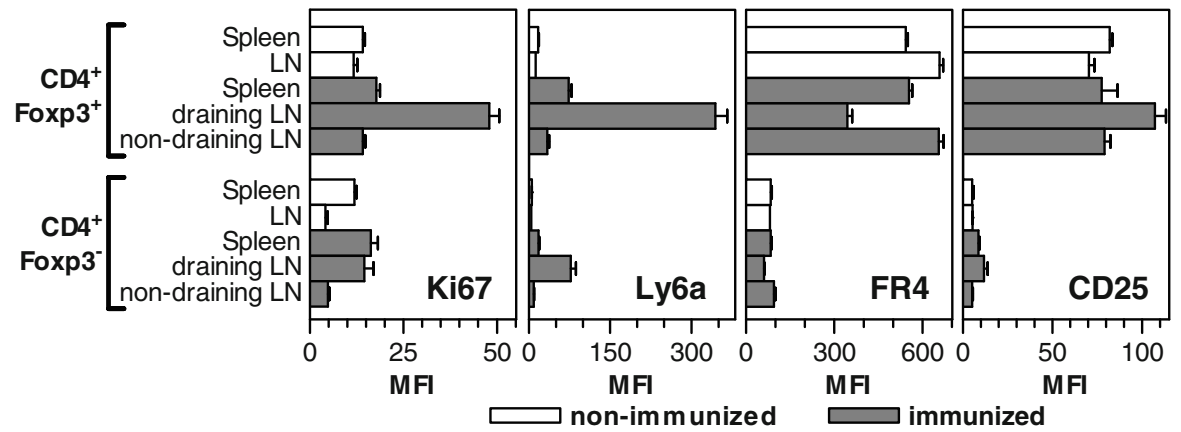


4 Fig. 2 Gene expression profiling of Treg after DC-based peptide immunization. a Isolation of $\mathrm{CD}^{+} \mathrm{CD} 25^{+} \mathrm{IL} 7 \mathrm{R}^{-}$Treg and $\mathrm{CD} 4{ }^{+} \mathrm{CD} 25^{-} \mathrm{IL} \mathrm{R}^{+}$splenocytes by flow cytometry. b Analysis of immunization-dependent changes in the Treg transcriptome. Left upper plot correlation of the common Treg signature [28] ( $x$ axis) with expression ratios of splenic naive Treg and Tconv in this study ( $y$ axis). Left lower plot comparison of induced changes in the common Treg signature under different stimulation conditions. A Treg stimulation index was calculated for every gene of the common Treg signature by dividing the expression ratio of stimulated Treg/stimulated Tconv through the expression ratio of naive Treg/ naive Tconv. $x$ axis Treg stimulation index derived from direct in vitro stimulation of TCR transgenic T cells with the cognate Ag [28]. $y$ axis Treg stimulation index derived from splenocytes after in vivo DC-based immunization of wild-type mice with MHC class Irestricted peptide epitopes. Right panel influence of DC-based immunization on the global Treg transcriptome depicted by fold change versus fold change $(\mathrm{FcFc})$ plot of expression ratios between Treg and Tconv from spleens of naive ( $x$ axis) and DC-immunized ( $y$ axis) mice. Blue dots indicate genes of the common Treg signature [28] Red dots indicate genes of a Treg activation signature defined by $>K$ twofold, highly significant $(q<0.01)$ immunization-induced expression difference in Treg and absence of a major expression difference (0.75-1.25fold change) in Tconv. c Expression of Ki67 and Ly6a in Treg and Tconv from various anatomical locations after $\mathbf{J}$ peptide immunization. d Summary of expression (mean and SEM) of selected proteins in Treg and Tconv. Non-immunized: $n=2$ animals. Immunized: $n=6$ animals ( 2 mice $\mathrm{J}$ immunized, 4 mice CDR3immunized)

\section{In vitro cytotoxicity assay}

T2 cells were pulsed with $10 \mu \mathrm{g} / \mathrm{ml}$ peptide overnight and stained with $5 \mu \mathrm{M}$ CFSE. $10^{4}$ target cells were incubated with effector T cells in different $E: T$ ratios for $4 \mathrm{~h}$. Cytotoxicity was determined by flow cytometry as the $\mathrm{CFSE}^{+}$/ propidium iodide $^{+}$cell fraction.

\section{Isolation and IL-10 production of $\mathrm{CD} 4{ }^{+} \mathrm{CD} 25^{+}$Treg}

$\mathrm{CD} 4{ }^{+} \mathrm{CD} 25^{+} \mathrm{T}$ cells were isolated from $\mathrm{LN}$ or spleen by depletion of non-CD4 ${ }^{+}$cells and subsequent positive selection of $\mathrm{CD} 25^{+}$cells (Regulatory T Cell Isolation Kit; Miltenyi). After 2 days of coculture of $1 \times 10^{6}$ cells of the $\mathrm{CD} 4^{-}$fraction with isolated $\mathrm{CD} 4{ }^{+} \mathrm{CD} 25^{+}$cells, the IL-10 concentration in the culture supernatant was determined by ELISA (BD Biosciences).

\section{Gene expression profiling of Treg}

$10 \mu \mathrm{g}$ of biotin-labeled and fragmented cRNA (MessageAmpTM II-Biotin Enhanced kit, Ambion AM1791) of splenic $\mathrm{CD} 4{ }^{+} \mathrm{CD} 25^{+} \mathrm{IL} \mathrm{R}^{-}$Treg [20] were hybridized to GeneChip Mouse Genome 4302.0 Arrays (Affymetrix, Santa Clara, CA, USA) at $45^{\circ} \mathrm{C}$ for $16 \mathrm{~h}$. The arrays were washed (FS450_0004 protocol, Fluidics Station FS450, Affymetrix), scanned (GeneChip 3000 7G Scanner, Affymetrix), and converted into CEL files (GeneChip
Command Console Software Version 1.0, Affymetrix). CEL files were imported into the Refiner module of Expressionist software 5.1.2 (Genedata, Basel, Switzerland), where RMA background subtraction, quantile normalization, and probe summarization with the median polish activity were performed using the Bioconductor RMA condensing algorithm [21]. Data were then imported into the Analyst module of Expressionist and further normalized by median scaling to an expression value of 200 over all probe sets except the bacterial spike probes. Differentially expressed genes were identified with an unpaired Bayes $T$ test (CyberT) with Bayes Confidence Estimate Value set to 10 and a window size of 101 genes [22]. False-discovery rates were estimated by the method of Benjamini and Hochberg [23]. Median expression ratios between Treg and Tconv were calculated for individual genes by the 'N-fold regulation'-activity of Analyst. Overor underrepresentation of certain gene ontologies within selected gene lists in Analyst was identified by Fisher's exact test with a $p$ value threshold of 0.001 and a property size threshold of 10 .

\section{Analysis of TCR repertoires}

cDNA was synthesized (Superscript II reverse transcriptase; Invitrogen, Carlsbad, CA, USA) from RNA isolated from $\mathrm{CD} 4{ }^{+} \mathrm{CD} 25^{+}$splenocytes 1 week after vaccination (RNeasy Kit; Qiagen, Hilden, Germany). $2 \mu \mathrm{l}$ of cDNA were amplified by PCR with $1 \mu \mathrm{M} \mathrm{V}$ and $\mathrm{C}$ primers and $0.1 \mathrm{U} / \mu \mathrm{l}$ of $\mathrm{Taq}$ polymerase (Qiagen) with an annealing temperature of $60^{\circ} \mathrm{C}$ [24]. PCR products were labeled with 6-FAM-labeled 3' C primer and PFU polymerase (Stratagene) for three cycles using an annealing temperature of $60^{\circ} \mathrm{C}$. Denatured labeled PCR products $(1.3 \mu \mathrm{l})$ were analyzed on an Prism 3110 XL Genetic Analyzer (Applied Biosystems, Foster City, CA, USA) with GeneScan 500 LIZ size standard and Genemapper 4.0 software 4.0 (Applied Biosystems).

\section{Results}

CDR3- but not $\mathrm{J}$ region-specific $\mathrm{T}$ cells are induced in vivo by $\mathrm{DC}$ immunization

We identified a $\mathrm{H}-2 \mathrm{~K}^{\mathrm{d}}$-restricted CDR3 peptide (YYC SISGDY) from the published A20 IgH sequence [25] by the BIMAS algorithm (http://www-bimas.cit.nih.gov/molbio/ hla_bind/). This peptide has no significant protein homologies as determined by BLAST search. The A20 J peptide DYWGQGTEL [26] contains two amino acids that are assigned to the CDR3 region. However, these residues are non-polymorphic, and a BLAST search of the J peptide yielded 

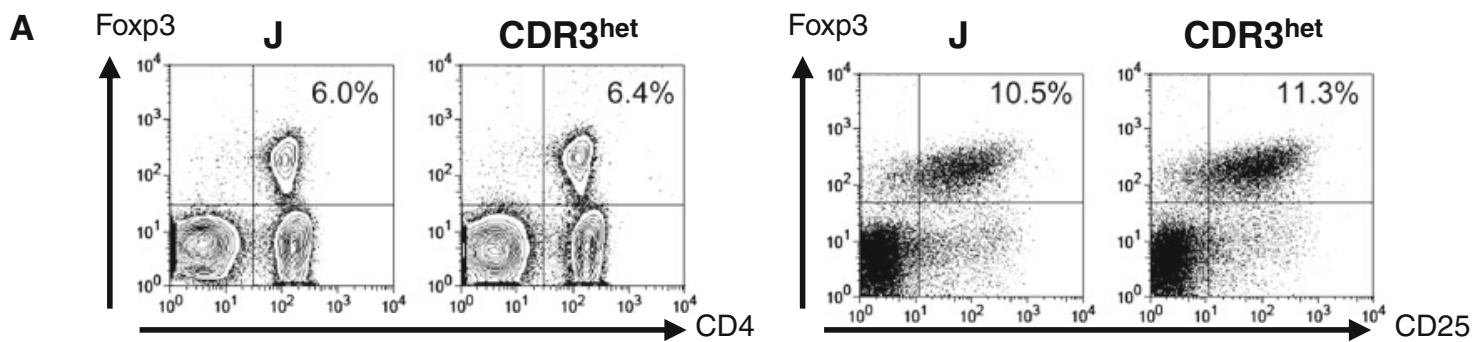

B Foxp3

CDR3 $^{\text {het }}$
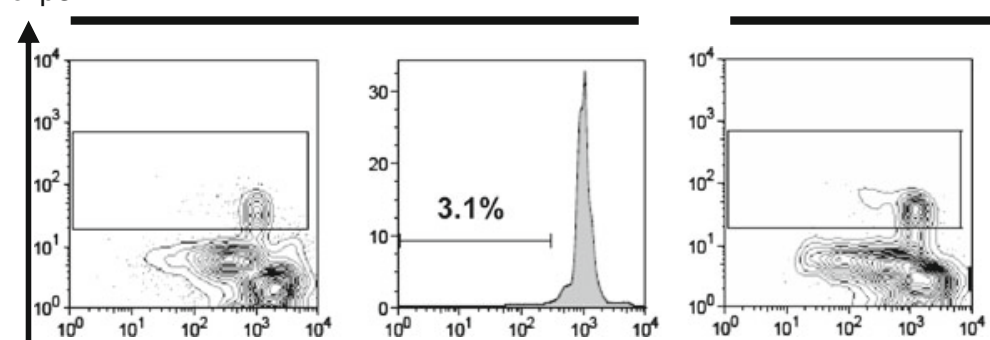

J
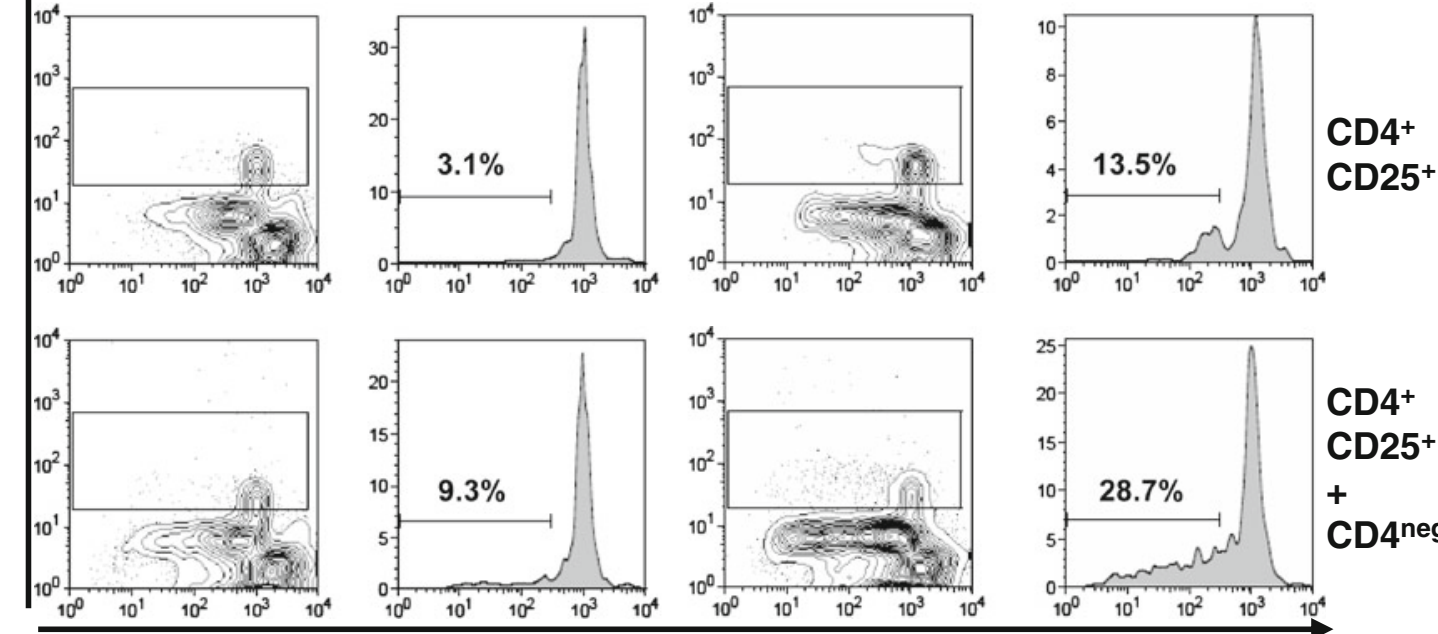

CFSE

C

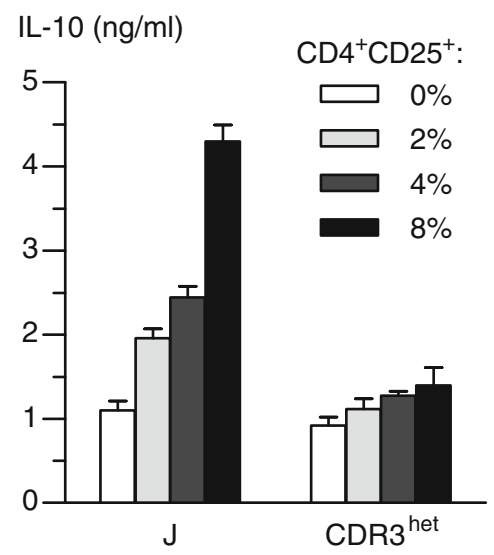

D IL-10 (ng/ml)
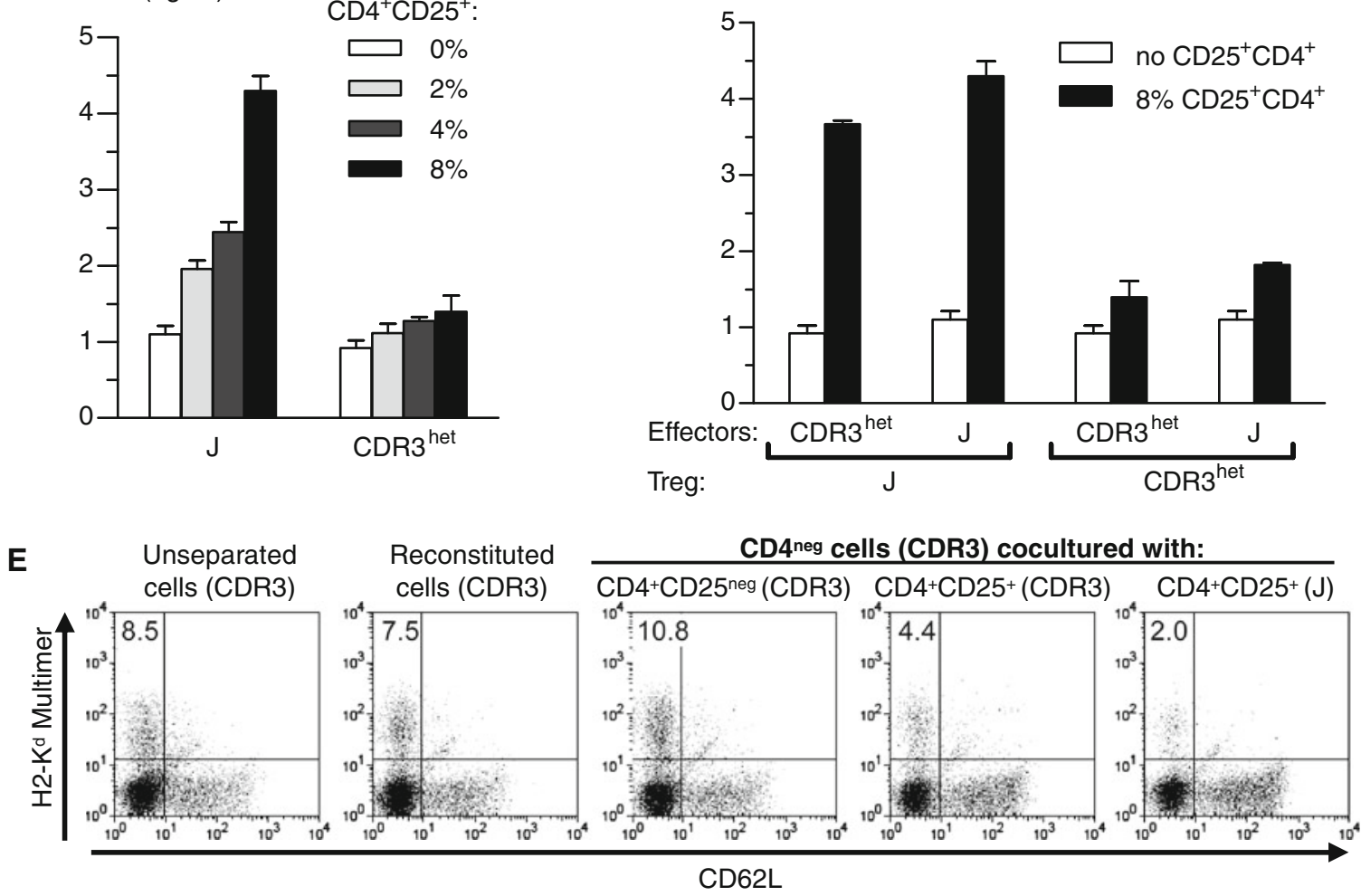
4 Fig. 3 Functional analyses of Treg after DC-based peptide immunization. a Proportion of $\mathrm{CD} 4{ }^{+} \mathrm{FoxP} 3^{+}$cells of total cells (left panels) and $\mathrm{CD} 25^{+} \mathrm{FoxP}^{+}$cells within the $\mathrm{CD}^{+}$population (right panels) in the draining LN. b Spontaneous in vitro proliferation of isolated $\mathrm{CD} 4{ }^{+} \mathrm{CD} 25^{+}$, CFSE-labeled LN cells from J- or CDR3-immunized mice during 1 week of culture in the presence or absence of the CD4 $4^{-}$ cell fraction of the same LN. Histograms depict gated $\mathrm{CD}^{+}{ }^{+} \mathrm{FoxP} 3^{+}$ cells as indicated by rectangles in corresponding contour plots. c Secretion of $\mathrm{IL}-10$ (mean and SEM) by $\mathrm{CD} 4{ }^{+} \mathrm{CD} 25^{+}$cells as detected by ELISA. Triplicates of $\mathrm{CD}^{-}$splenocytes from either J- or CDR3-immunized mice were cultured with the vaccine peptide together with $\mathrm{CD} 4{ }^{+} \mathrm{CD} 25^{+}$splenocytes from the same animals. d Agdependent IL-10 secretion (mean and SEM) by immunization-induced Treg as detected by ELISA. Triplicates of $\mathrm{CD}^{-}{ }^{-}$splenocytes from Jor CDR3- immunized mice were cultured with the vaccine peptide with or without addition of $8 \% \mathrm{CD} 4{ }^{+} \mathrm{CD} 25^{+}$Treg from J- or CDR3immunized mice. e Inhibition of CDR3-specific effector cells by CDR3- or J-induced Treg in vitro. CD4 ${ }^{-}$splenocytes from CDR3immunized mice were restimulated for 1 week with CDR3 peptide together with isolated subpopulations of splenocytes from CDR3- or J-immunized mice as indicated. CDR3-specific effector cells were measured with CDR3 peptide/ $\mathrm{H}-2 \mathrm{~K}^{\mathrm{d}}$ multimer complexes and anti$\mathrm{CD} 62 \mathrm{~L}$ in the $\mathrm{CD} 8^{+}$population by flow cytometry. Reconstituted cells comprise mixture of $\mathrm{CD} 4^{-}, \mathrm{CD} 4^{+} \mathrm{CD} 25^{-}$, and $\mathrm{CD} 4^{+} \mathrm{CD} 25^{+}$ cells from CDR3-immunized spleens according to their natural composition

hundreds of matches with murine IgH sequences (data not shown).

Single immunization of mice with DC loaded with the HA peptide IYSTVASSL [17] efficiently induced specific effector T cells (Fig. 1a). Immunization with a heteroclitic version [27] of the CDR3 peptide (CDR $3^{\text {het }}$, YYCSISGDL) induced Ag-specific $\mathrm{T}$ cells that also recognized the native CDR3 peptide (Fig. 1b). Immunization with the J peptide failed to induce a detectable $\mathrm{T}$ cell response (Fig. 1a). Since the $\mathrm{J}$ peptide effected the highest $\mathrm{H}-2 \mathrm{~K}^{\mathrm{d}}$ stabilization in a T2 binding assay, the differential immunogenicity of the peptides was not attributable to MHC binding (Fig. 1c). Peptide-pulsed target cells were eliminated in vivo in HAand CDR3-immunized but not in J-immunized animals (Fig. 1d). In contrast, in vitro restimulation expanded Agspecific $\mathrm{T}$ cells with strong specific cytotoxicity from all three immunization groups (Fig. 1a, e).

To explore how dependent the lack of $\mathrm{J}$ peptide in vivo immunogenicity was on its precise amino acid sequence, we immunized mice with a mutated $\mathrm{J}$ peptide ( $\mathrm{J}^{\mathrm{mut}}$; DYWEQTEL). This minor modification resulted in high frequencies of peptide-specific splenocytes (Fig. 1f) and moderate but robust in vivo cytotoxicity of $\mathrm{J}^{\text {mut }}$-induced effectors (Fig. 1g).

DC-based peptide $\mathbf{J}$ immunization induces Treg activity in vivo

Since the discrepancy between in vivo and in vitro cytotoxicity after $\mathbf{J}$ immunization suggested Treg as a potential suppressor mechanism of $\mathrm{J}$-specific $\mathrm{T}$ cells in vivo, we performed gene expression profiling of splenic CD4 ${ }^{+} \mathrm{CD} 25^{+} \mathrm{IL}^{-} \mathrm{R}^{-}$Treg [20] (Fig. 2a). The Treg phenotype was validated by the expression of Il2ra (CD25), FoxP3, Tnfrsf18 (GITR), and Ctla4 (Supplemental Table 1). Expression of the 603 genes of the so-called "common Treg signature" [28] correlated with published data in naive mice $(r=0.68, p<0.0001$; Supplemental Table 2). This signature was also stable after DC-based immunization ( $r=0.82, p<10^{-15}$; blue dots in Fig. 2b). The Treg-specific expression of genes linked to Treg function (annotated in Fig. 2b) was better preserved after DC-based immunization in vivo than published for direct TCR-mediated Treg stimulation in vitro [28].

A reaction of splenic Treg to DC-based immunization was indicated by significant $\left(q<0.01 ; p=2.2 \times 10^{-7}\right.$ $\left.2.4 \times 10^{-14}\right)$, at least twofold transcriptional change in 1,266 genes (1,098 up- and 168 downregulated). Immunization-induced transcriptional regulation of 300 of these 1,266 genes was restricted to Treg as indicated by an expression ratio of $0.75-1.25$ between splenic conventional $\mathrm{T}$ cells (Tconv) from immunized and naive mice (red dots in Fig. 2b). Only 6 of these 300 genes (2\%) were members of the common Treg signature, and only two genes (Dock10, Wnk1) were known FoxP3 target genes [29]. However, these 300 genes included the upregulated Treg effector cytokine TGF-beta [30], and testing for enriched gene ontology groups identified post-translational protein modification by phosphatase activity (Ppp1cb, Sbf1, Ptp4a3, Ppp5c), gene silencing by methylation (Dnmt3a, Eif2c2, Eif2c3, Adar, Dnmt1), and inhibition of translation initiation (Eif4ebp2, Eif4ebp3) as processes that were significantly enhanced (Supplemental Table 3).

The transcriptional upregulation of Ly6a in splenic Treg was verified in comparison to the Treg surface markers CD25 and folate receptor 4 [31] by flow cytometry for Tconv and FoxP3 $^{+}$Treg from various anatomical locations (Fig. 2c, d). Vaccination-induced changes of these markers were most pronounced in the draining LN. Intracellular expression of Ki67, which was upregulated 2.05-fold in splenic Treg after vaccination $\left(p=3.12 \times 10^{-6}, q=0.13\right)$, indicated a proliferative response of Treg to DC-based immunization that was higher in the draining LN than in the spleen (Fig. 2c, d). However, even in the draining LN, we were unable to detect any significant differences between J- or CDR3-immunized mice with respect to phenotype (not shown) or total numbers of $\mathrm{CD} 4{ }^{+} \mathrm{CD} 25^{+}$FoxP3 ${ }^{+}$Treg (Fig. 3a).

Induction of Treg suppressive function by $\mathbf{J}$ peptide immunization

After $\mathrm{J}$ immunization, FoxP3 ${ }^{+}$Treg from the draining LN proliferated spontaneously in vitro (Fig. 3b). In cocultures of $\mathrm{CD}^{+}{ }^{+} \mathrm{CD} 25^{+} \mathrm{T}$ cells with $\mathrm{CD} 4^{-} \mathrm{T}$ cells, substantial 
A
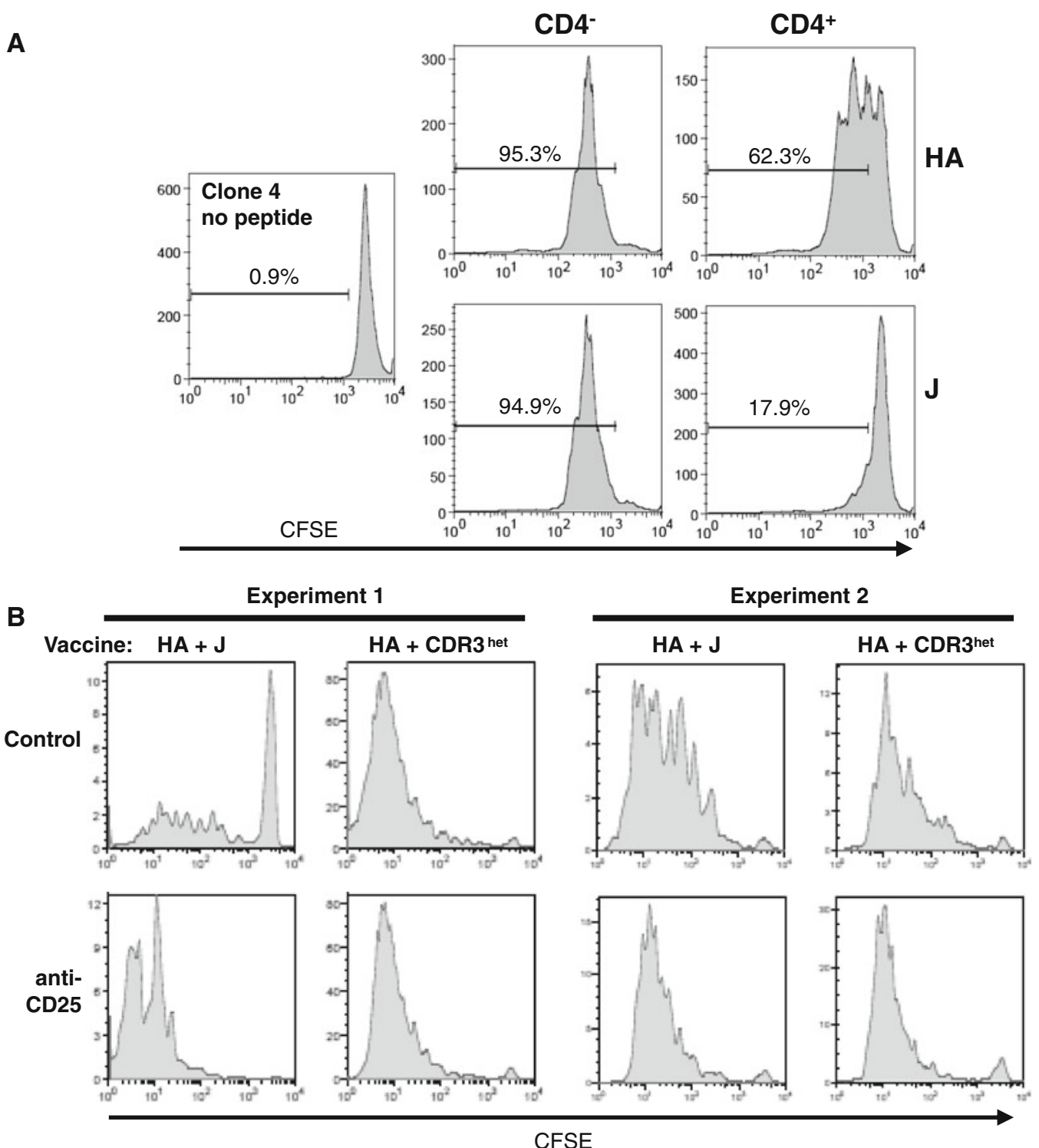

C $\mathrm{HA} / \mathrm{H}-2 \mathrm{~K}^{\mathrm{d}}$

Multimer

Lymph Node
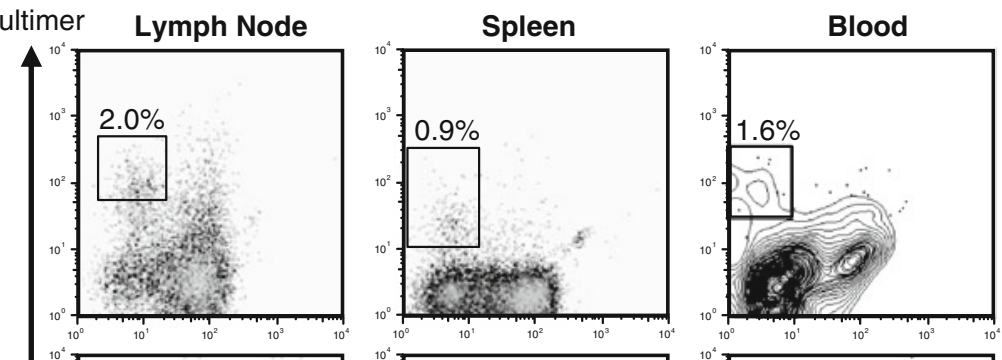

separately

immunized
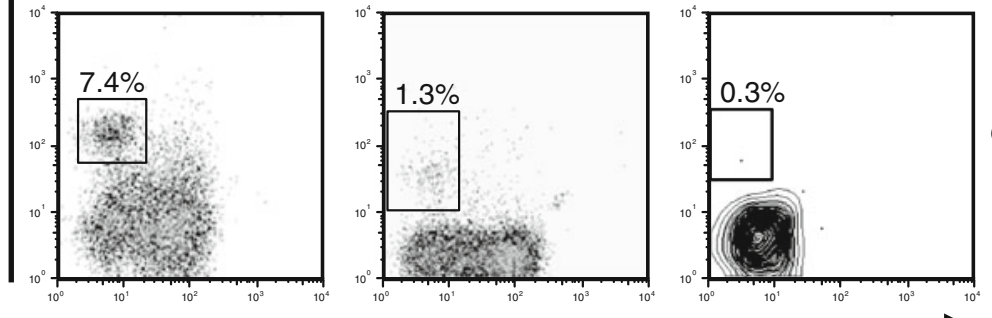

CD62L 
4Fig. 4 Suppression of HA-specific T cells by $\mathrm{J}$ immunization in vitro and in vivo. a Ag-dependent suppression of clone $4 \mathrm{~T}$ cells in vitro. Naive, CFSE-labeled CD $8^{+} \mathrm{CD} 45.1^{+}$clone $4 \mathrm{~T}$ cells were incubated with $\mathrm{CD} 4^{-}$or $\mathrm{CD} 4^{+}$splenocytes from mice immunized with $\mathrm{HA}$ or $\mathrm{J}$ peptide in the presence of $10 \mu \mathrm{M}$ peptide and analyzed after 3 days. b Ag-dependent suppression of clone $4 \mathrm{~T}$ cells in vivo. CD45.1/ CD45.2 heterozygous B10.D2 mice with and without prior depletion of $\mathrm{CD} 25^{+}$cells were immunized with DC loaded with equal amounts of HA and either CDR3 or J peptide. 3 days later, CFSE-labeled, $\mathrm{CD} 45.1^{+/+} \mathrm{CD}^{+}$clone 4 cells were injected i.v. 1 week after immunization, $\mathrm{CD}^{+} \mathrm{CD} 45.2^{-}$and $\mathrm{HA}$ peptide/ $\mathrm{H}-2 \mathrm{~K}^{\mathrm{d}}$ multimerpositive splenocytes were measured. c Effects of co-immunization with HA and $J$ peptide on the induction of HA-specific $T$ cells. $\mathrm{BALB} / \mathrm{c}$ mice were immunized with DC loaded with equal concentrations of $\mathrm{HA}$ and $\mathrm{J}$ peptide (co-immunized) or immunized separately into contralateral hind paws with DC loaded only with HA or J peptide. HA-specific T cells were measured after 1 week

amounts of IL-10 were detected after $\mathrm{J}$ immunization depending on the cellular proportion (Fig. 3c) and independent of the effector $\mathrm{T}$ cell specificity (Fig. $3 \mathrm{~d}$ ). $\mathrm{CD} 4^{+} \mathrm{CD} 25^{+}$ Treg from J-immunized animals suppressed peptide-induced in vitro expansion of $\mathrm{CDR} 3$-specific $\mathrm{CD} 8^{+}$splenocytes stronger than CDR3-induced cells (Fig. 3e).

J peptide-induced Treg suppress T cell responses to HA at different stages

HA peptide stimulation induced vigorous in vitro proliferation of naive clone $4 \mathrm{~T}$ cells in the presence of $\mathrm{CD}^{-}$ splenocytes from HA- or J-immunized animals (Fig. 4a). $\mathrm{CD}^{+}$splenocytes from J-immunized mice suppressed peptide-induced clone $4 \mathrm{~T}$ cell proliferation more efficiently than $\mathrm{CD}^{+}$splenocytes from HA-immunized mice.

To investigate the effects of co-immunization of the $\mathrm{J}$ peptide with the highly immunogenic HA peptide on HAspecific $\mathrm{T}$ cell responses in vivo, mice were immunized once with DC co-loaded with both the HA peptide and either the J or CDR3 peptide. HA-specific transgenic clone $4 \mathrm{~T}$ cells were adoptively transferred 3 days later. HAspecific $\mathrm{T}$ cells proliferated vigorously in mice co-immunized with HA and CDR3 peptide (Fig. 4b). Co-immunization with $\mathrm{HA}$ and $\mathrm{J}$ resulted in markedly reduced proliferation of HA-specific $\mathrm{T}$ cells. Depletion of Treg prior to immunization prevented this inhibition.

Finally, we examined the influence of J peptide coimmunization on the initiation of non-TCR-transgenic HAspecific T cells in wild-type mice in vivo. Mice were either immunized with DC loaded with HA and J peptide, or simultaneously with HA peptide-loaded DC into one leg and $\mathrm{J}$ peptide-loaded DC into the contralateral leg. The frequency of HA-specific effector $\mathrm{T}$ cells in the draining LN was increased after co-immunization with both peptides at the same location (Fig. 4c). However, HA-specific $\mathrm{T}$ cells circulated only when the HA immunization was anatomically separated from the J peptide. These findings
Fig. 5 Analysis of the Treg TCR repertoire 1 week after DC-based immunization against $\mathrm{J}$ and $\mathrm{CDR} 3^{\text {het }}$ peptide. a Distribution of TCR V $\beta$ families within $\mathrm{CD} 4^{+} \mathrm{FoxP}^{+}$ cells as detected by flow cytometry in the draining lymph node. b V $\beta$ CDR3 length distribution of isolated $\mathrm{CD} 4^{+} \mathrm{CD} 25^{+}$splenocytes analyzed by spectratype PCR with $\mathrm{V} \beta$ and $\mathrm{C}$ specific primers

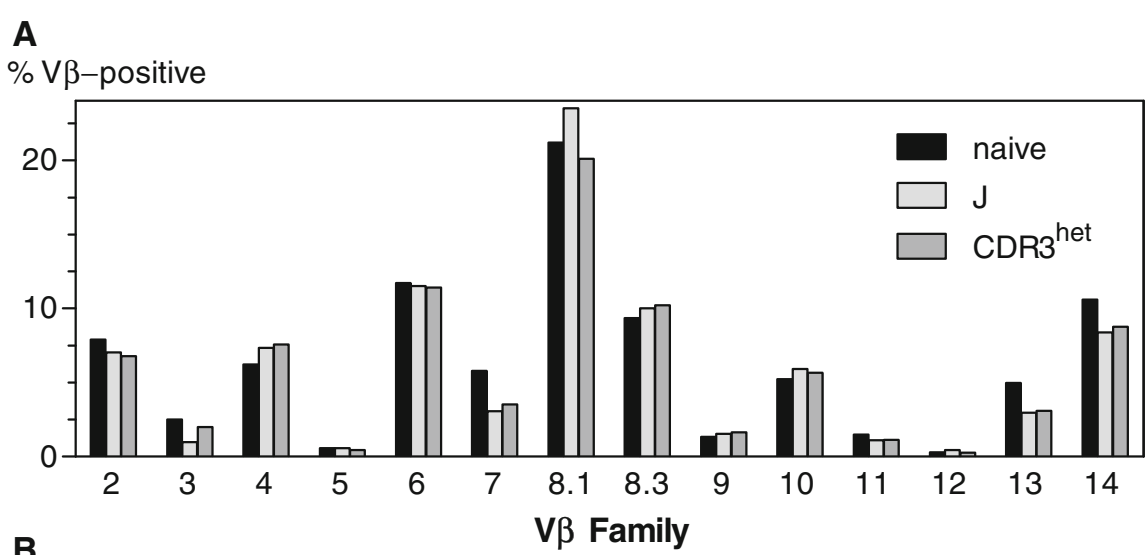

B

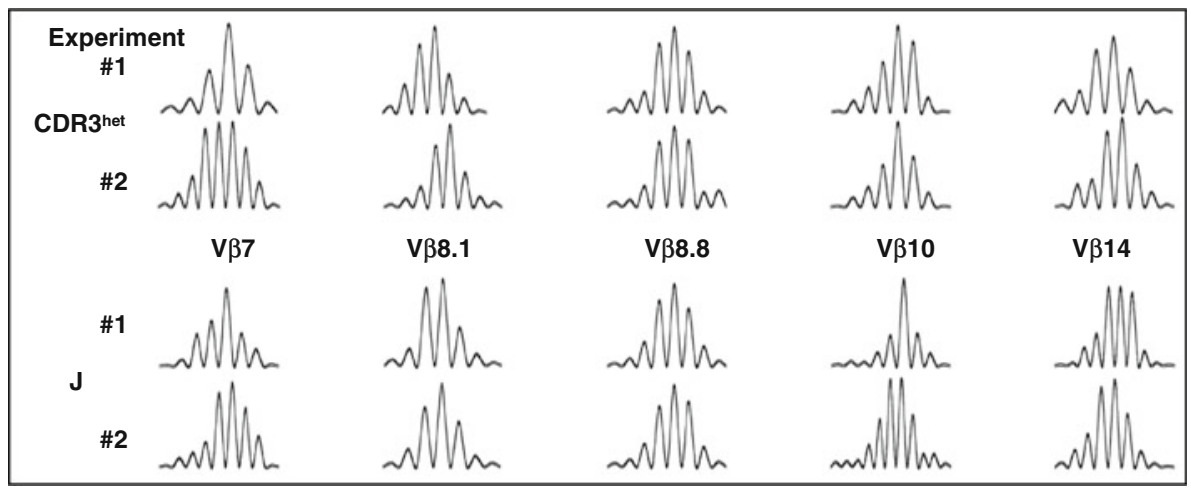


raise the possibility that co-immunization with the $\mathrm{J}$ peptide did not affect the induction and initial local expansion of HA-specific $\mathrm{T}$ cells, but possibly reduce their egress from the $\mathrm{LN}$ despite the downregulation of CD62L.

The Treg TCR repertoire after DC-based peptide immunization

The differential activity of Treg upon CDR3- and J-immunization prompted us to search for vaccinationdependent changes of the Treg TCR repertoire. However, there was no detectable difference in the distribution of TCR V $\beta$ families in the draining lymph node (Fig. 5a). In addition, no skewing of the CDR length within $\mathrm{V} \beta$ transcripts of splenic Treg became apparent after DC-based immunization (Fig. 5b).

\section{Discussion}

Natural Treg have the primary function to control autoreactive $T$ cells in the periphery [32]. Treg may be induced by organ-specific self $\mathrm{Ag}$ and recognize such $\mathrm{Ag}$ through their TCR [33, 34]. When A20 cells expressing HA as an artificial tumor $\mathrm{Ag}$ are transferred into mice with HAspecific, MHC class II-restricted transgenic $\mathrm{T}$ cells, immunization against HA expands both HA-specific effector cells and suppressive cells including Treg [35]. A dominance of suppression over effector function prevents therapeutic vaccination efficacy in this model.

In contrast to a predetermined specificity of Treg through a transgenic TCR, our experiments are performed by immunizations with MHC class I-restricted peptides and in a natural $\mathrm{T}$ cell repertoire. The development of a serumfree protocol to generate "fully licensed" DC in vitro [18] and the identification of an immunogenic CDR3 peptide of the A20 Id enabled us to interrogate the possible extremes in Id vaccination, i.e. to analyze responses to a unique CDR3 peptide versus a FR4/J peptide expressed by many normal B cells. We identified transcriptional changes induced in Treg by an MHC class I-restricted Ag in wildtype mice and compared these transcriptomes to direct Treg stimulation enforced through a transgenic TCR [28]. Since the common Treg signature was considerably more stable after in vivo Treg activation by DC, our experimental system may recapitulate the behavior of Treg in a natural immune response more accurately. We identified upregulation of known Treg effector and cellular interaction molecules, e.g. granzymes, IL-10, TGF-beta [30], neuropilin [36], CXCR6, CD44, and CD18 [37, 38]. Transcriptional induction of protein dephosphorylation, DNA methylation, and inhibition of translation initiation may also be required for suppressive Treg function in an immunostimulatory environment induced by activated and licensed DC [18].

Only the $\mathrm{J}$ peptide effected a proliferation of Treg isolated from the draining $\mathrm{LN}$ despite similar phenotypic and transcriptional changes in splenic Treg after both immunizations. In addition, TCR repertoire and transcriptome of Treg were practically indistinguishable after immunization with immunogenic and nonimmunogenic peptides. Therefore, the magnitude rather than a particular quality of the Treg response may determine the outcome of peptide immunization. Consistent with this hypothesis, the vaccine formulation may have a critical impact on the immunization efficacy, since the Treg-inducing $\mathrm{J}$ epitope was originally identified as a protective $\mathrm{Ag}$ after adenoviral Id vaccination [26].

The peptides used in this study cannot be recognized by the MHC class II-restricted TCR of Treg. Therefore, the J-induced Treg response must involve an indirect mechanism. We assume that the immigrating DCs induce $\mathrm{Ag}$-specific T cells in the draining $\mathrm{LN}$. In the case of the CDR3 and HA peptides, these T cells do not encounter their antigen on other cells and are able to establish systemic immunity. In contrast, J-specific $\mathrm{T}$ cells can encounter their cognate antigen on other resident $\mathrm{B}$ cells immediately after activation, and the resulting release of self Ags from these B cells could lead to efficient activation of resident Treg.

Treg may suppress specific $\mathrm{T}$ cell responses by inhibiting their amplification through proliferation [39] and acting directly at the site of $\mathrm{T}$ cell activation [40]. Both levels of inhibition may be operational in our experimental system: J peptide-activated Treg exerted systemic inhibition of Ag-specific $\mathrm{T}$ cell proliferation. However, we also find preliminary evidence for an impaired exit of activated $\mathrm{CD}^{+}$cells from the draining $\mathrm{LN}$ after co-immunization with the J peptide.

In summary, our data identify Treg-mediated peripheral tolerance as a mechanism controlling the specificity of vaccination-induced anti-Id cellular immunity. In this model, a peptide shared between neoplastic and normal cells can suppress effector $\mathrm{T}$ cell activity against unique tumor-derived and microbial epitopes. The absence of Treg in in vitro stimulation cultures of isolated $\mathrm{CD}^{+} \mathrm{T}$ cells may also permit recognition of FR peptides [41]; however, this $\mathrm{T}$ cell activity would be expected to be suppressed in vivo by Treg. Treg activity may also explain the observed specificity of vaccination-induced $\mathrm{T}$ cell responses for CDR and hypermutated epitopes in lymphoma patients [3, $15,16]$ and the dominant role of CDR epitopes in Iddirected immunosurveillance despite better HLA-binding capacity of FR peptides [14]. An individual idiotype's net immunogenicity is presumably dependent on the balance between individual immunogenic epitopes and the suppressive effects of conserved peptides. This critical balance 
could offer a plausible, albeit difficult to prove, explanation for lack of cellular and perhaps humoral immune responses as observed in individual patients in clinical Id vaccination trials $[2-7,16]$.

Acknowledgments This work was supported by a grant from Wilhelm Sander-Foundation, Munich (2006.049.1), and by the Federal Ministry of Education and Research (BMBF) for the Freiburg Initiative for Systems Biology FRISYS (0313921). We thank H. Pircher for critical discussions.

Conflict of interest The authors declare that they have no conflict of interest.

Open Access This article is distributed under the terms of the Creative Commons Attribution Noncommercial License which permits any noncommercial use, distribution, and reproduction in any medium, provided the original author(s) and source are credited.

\section{References}

1. Stevenson GT, Elliott EV, Stevenson FK (1977) Idiotypic determinants on the surface immunoglobulin of neoplastic lymphocytes: a therapeutic target. Fed Proc 36(9):2268-2271

2. Bendandi M, Gocke CD, Kobrin CB, Benko FA, Sternas LA, Pennington R, Watson TM, Reynolds CW, Gause BL, Duffey PL, Jaffe ES, Creekmore SP, Longo DL, Kwak LW (1999) Complete molecular remissions induced by patient-specific vaccination plus granulocyte-monocyte colony-stimulating factor against lymphoma. Nat Med 5(10):1171-1177

3. Bertinetti C, Zirlik K, Heining-Mikesch K, Ihorst G, Dierbach H, Waller CF, Veelken H (2006) Phase I trial of a novel intradermal idiotype vaccine in patients with advanced B-cell lymphoma: specific immune responses despite profound immunosuppression. Cancer Res 66(8):4496-4502

4. Hsu FJ, Benike C, Fagnoni F, Liles TM, Czerwinski D, Taidi B, Engleman EG, Levy R (1996) Vaccination of patients with B-cell lymphoma using autologous antigen-pulsed dendritic cells. Nat Med 2(1):52-58

5. Hsu FJ, Caspar CB, Czerwinski D, Kwak LW, Liles TM, Syrengelas A, Taidi-Laskowski B, Levy R (1997) Tumorspecific idiotype vaccines in the treatment of patients with B-cell lymphoma-long-term results of a clinical trial. Blood 89(9): 3129-3135

6. Inoges S, Rodriguez-Calvillo M, Zabalegui N, Lopez-Diaz de Cerio A, Villanueva H, Soria E, Suarez L, Rodriguez-Caballero A, Pastor F, Garcia-Munoz R, Panizo C, Perez-Calvo J, Melero I, Rocha E, Orfao A, Bendandi M (2006) Clinical benefit associated with idiotypic vaccination in patients with follicular lymphoma. J Natl Cancer Inst 98(18):1292-1301

7. Weng WK, Czerwinski D, Timmerman J, Hsu FJ, Levy R (2004) Clinical outcome of lymphoma patients after idiotype vaccination is correlated with humoral immune response and immunoglobulin g fc receptor genotype. J Clin Oncol 22(23):4717-4724

8. Levy R, Robertson M, Leonard J, Vose J, Denney D (2008) Results of a phase 3 trial evaluating safety and efficacy of specific immunotherapy, recombinant idiotype (Id) conjugated to KLH (Id-KLH) with GM-CSF, compared to non-specific immunotherapy, KLH with GM-CSF, in patients with follicular nonhodgkin's lymphoma (fNHL). Ann Oncol 19(Suppl 4):iv101
9. Lauritzsen GF, Weiss S, Dembic Z, Bogen B (1994) Naive idiotype-specific CD4+ T cells and immunosurveillance of B-cell tumors. Proc Natl Acad Sci USA 91(12):5700-5704

10. Kwak LW, Young HA, Pennington RW, Weeks SD (1996) Vaccination with syngeneic, lymphoma-derived immunoglobulin idiotype combined with granulocyte/macrophage colony-stimulating factor primes mice for a protective T-cell response. Proc Natl Acad Sci USA 93(20):10972-10977

11. Levitsky HI, Montgomery J, Ahmadzadeh M, Staveley-O'Carroll K, Guarnieri F, Longo DL, Kwak LW (1996) Immunization with granulocyte-macrophage colony-stimulating factor-transduced, but not B7-1-transduced, lymphoma cells primes idiotype-specific $\mathrm{T}$ cells and generates potent systemic antitumor immunity. J Immunol 156(10):3858-3865

12. Bogen B, Ruffini P (2009) Review: to what extent are T cells tolerant to immunoglobulin variable regions? Scand J Immunol 70(6):526-530

13. Osterroth F, Garbe A, Fisch P, Veelken H (2000) Stimulation of cytotoxic $\mathrm{T}$ cells against idiotype immunoglobulin of malignant lymphoma with protein-pulsed or idiotype-transduced dendritic cells. Blood 95(4):1342-1349

14. Strothmeyer AM, Papaioannou D, Duhren-von Minden M, Navarrete M, Zirlik K, Heining-Mikesch K, Veelken H (2010) Comparative analysis of predicted HLA binding of immunoglobulin idiotype sequences indicates T-cell-mediated immunosurveillance in follicular lymphoma. Blood 116(10):1734-1736

15. Baskar S, Kobrin CB, Kwak LW (2004) Autologous lymphoma vaccines induce human $\mathrm{T}$ cell responses against multiple, unique epitopes. J Clin Invest 113(10):1498-1510

16. Navarrete MA, Heining-Mikesch K, Bertinetti-Lapatki C, Duehren-von Minden M, Hafkemeyer A, Veelken H (2008) Vaccination with recombinant idiotype Fab fragments induces specific cellular immunity and clinical responses in untreated Bcell lymphoma patients. Blood 112(11):235

17. Tamura M, Kuwano K, Kurane I, Ennis FA (1998) Definition of amino acid residues on the epitope responsible for recognition by influenza a virus H1-specific, H2-specific, and H1- and H2-crossreactive murine cytotoxic T-lymphocyte clones. J Virol 72(11):9404-9406

18. Warncke M, Dodero A, Dierbach H, Follo M, Veelken H (2006) Murine dendritic cells generated under serum-free conditions have a mature phenotype and efficiently induce primary immune responses. J Immunol Methods 310(1-2):1-11

19. Morgan DJ, Liblau R, Scott B, Fleck S, McDevitt HO, Sarvetnick N, Lo D, Sherman LA (1996) Cd8(+) T cell-mediated spontaneous diabetes in neonatal mice. J Immunol 157(3):978-983

20. Liu W, Putnam AL, Xu-Yu Z, Szot GL, Lee MR, Zhu S, Gottlieb PA, Kapranov P, Gingeras TR, Fazekas de St Groth B, Clayberger C, Soper DM, Ziegler SF, Bluestone JA (2006) CD127 expression inversely correlates with FoxP3 and suppressive function of human CD4+ T reg cells. J Exp Med 203(7):1701-1711

21. Irizarry RA, Hobbs B, Collin F, Beazer-Barclay YD, Antonellis KJ, Scherf U, Speed TP (2003) Exploration, normalization, and summaries of high density oligonucleotide array probe level data. Biostatistics 4(2):249-264

22. Baldi P, Long AD (2001) A bayesian framework for the analysis of microarray expression data: regularized $t$-test and statistical inferences of gene changes. Bioinformatics 17(6):509-519

23. Benjamini Y, Hochberg Y (1995) Controlling the false discovery rate: a practical and powerful approach to multiple testing. J R Stat Soc Series B Stat Methodol 57:289-300

24. Pannetier C, Cochet M, Darche S, Casrouge A, Zoller M, Kourilsky P (1993) The sizes of the CDR3 hypervariable regions of the murine T-cell receptor beta chains vary as a function of the recombined germ-line segments. Proc Natl Acad Sci USA 90(9):4319-4323 
25. Doenecke A, Winnacker EL, Hallek M (1997) Rapid amplification of cDNA ends (race) improves the PCR-based isolation of immunoglobulin variable region genes from murine and human lymphoma cells and cell lines. Leukemia 11(10):1787-1792

26. Armstrong AC, Dermime S, Allinson CG, Bhattacharyya T, Mulryan K, Gonzalez KR, Stern PL, Hawkins RE (2002) Immunization with a recombinant adenovirus encoding a lymphoma idiotype: induction of tumor-protective immunity and identification of an idiotype-specific $\mathrm{T}$ cell epitope. J Immunol 168(8):3983-3991

27. Dyall R, Bowne WB, Weber LW, LeMaoult J, Szabo P, Moroi Y, Piskun G, Lewis JJ, Houghton AN, Nikolic-Zugic J (1998) Heteroclitic immunization induces tumor immunity. J Exp Med 188(9):1553-1561

28. Hill JA, Feuerer M, Tash K, Haxhinasto S, Perez J, Melamed R, Mathis D, Benoist C (2007) FoxP3 transcription-factor-dependent and -independent regulation of the regulatory $\mathrm{T}$ cell transcriptional signature. Immunity 27(5):786-800

29. Zheng Y, Josefowicz SZ, Kas A, Chu TT, Gavin MA, Rudensky AY (2007) Genome-wide analysis of FoxP3 target genes in developing and mature regulatory $\mathrm{T}$ cells. Nature 445(7130): 936-940

30. Groux H, O'Garra A, Bigler M, Rouleau M, Antonenko S, de Vries JE, Roncarolo MG (1997) A CD4+ T-cell subset inhibits antigen-specific T-cell responses and prevents colitis. Nature 389(6652):737-742

31. Yamaguchi T, Hirota K, Nagahama K, Ohkawa K, Takahashi T, Nomura T, Sakaguchi S (2007) Control of immune responses by antigen-specific regulatory $\mathrm{T}$ cells expressing the folate receptor. Immunity 27(1):145-159

32. Sakaguchi S, Yamaguchi T, Nomura T, Ono M (2008) Regulatory $\mathrm{T}$ cells and immune tolerance. Cell 133(5):775-787
33. Rudensky AY, Campbell DJ (2006) In vivo sites and cellular mechanisms of $\mathrm{T}$ reg cell-mediated suppression. J Exp Med 203(3):489-492

34. Apostolou I, Sarukhan A, Klein L, von Boehmer H (2002) Origin of regulatory $\mathrm{T}$ cells with known specificity for antigen. Nat Immunol 3(8):756-763

35. Zhou G, Drake CG, Levitsky HI (2006) Amplification of tumorspecific regulatory $\mathrm{T}$ cells following therapeutic cancer vaccines. Blood 107(2):628-636

36. Sarris M, Andersen KG, Randow F, Mayr L, Betz AG (2008) Neuropilin-1 expression on regulatory $T$ cells enhances their interactions with dendritic cells during antigen recognition. Immunity 28(3):402-413

37. Lim HW, Broxmeyer HE, Kim CH (2006) Regulation of trafficking receptor expression in human forkhead box P3+ regulatory T cells. J Immunol 177(2):840-851

38. Marski M, Kandula S, Turner JR, Abraham C (2005) CD18 is required for optimal development and function of CD4+ CD25+ T regulatory cells. J Immunol 175(12):7889-7897

39. Edinger M, Hoffmann P, Ermann J, Drago K, Fathman CG, Strober S, Negrin RS (2003) CD4+ CD25+ regulatory T cells preserve graft-versus-tumor activity while inhibiting graft-versushost disease after bone marrow transplantation. Nat Med 9(9):1144-1150

40. Mempel TR, Pittet MJ, Khazaie K, Weninger W, Weissleder R, von Boehmer H, von Andrian UH (2006) Regulatory T cells reversibly suppress cytotoxic $\mathrm{T}$ cell function independent of effector differentiation. Immunity 25(1):129-141

41. Trojan A, Schultze JL, Witzens M, Vonderheide RH, Ladetto M, Donovan JW, Gribben JG (2000) Immunoglobulin frameworkderived peptides function as cytotoxic T-cell epitopes commonly expressed in B-cell malignancies. Nat Med 6(6):667-672 